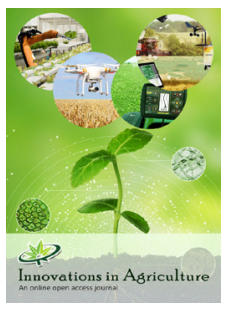

Received: February 21, 2019 Accepted: April 09, 2019 Published: April 12, 2019

*Corresponding Author: Muhammad Arshad Ullah Email: arshadullah1965@ gmail.com

\section{Growth assessment of tinda gourd (Praecitrullus fistulosu) germplasms}

\author{
Asfand Raheel', Awais Ghani', Raheel Babar², Muhammad Arshad Ullah', \\ Ali Zaffar', Muzammil Jahangir'1, Maouz Iqbal'
}

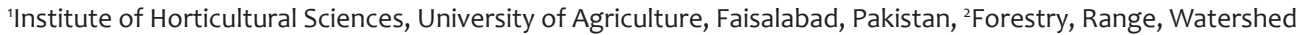
and Wildlife management, Baluchistan Agriculture College, Quetta, Pakistan, ${ }^{3}$ Land Resources Research Institute, National Agricultural Research Centre, Islamabad- 45500, Pakistan

\begin{abstract}
A field experiment was conducted to identify growth pattern and morphological traits of 16 varietal lines of Tinda gourd specie (Praecitrullus fistulosus) germplasms. The field experiment was conducted in olericulture area of Institute of Horticultural Sciences, University of Agriculture, Faisalabad. One local variety as check with fifteen genotypes of Tinda gourd was grown in Olericulture field. Flat beds technique as growing medium was applied in field for seeds to germinate. Data on germination percentage, days to flowering, male flower ratio, female flower ratio, length of vine in $(\mathrm{cm})$ and tendrils which were taken as phenotypically. Data were analyzed statistically by using method ANOVA and their means were compared by using SE techniques. The maximum Germination percentage $\left(\mathrm{G}_{\%}\right)$, DTF (days to flowering), MF (male flower), FF (female flower) and $\mathrm{LV}$ (length of vine) were recorded was $\mathrm{L}_{0}(94.00), \mathrm{L}_{0}(54.33)$, $\mathrm{L}_{11}(110.33), \mathrm{L}_{11}(14.33)$ and $\mathrm{L}_{0}(55.33)$ and the minimum were recorded was $\mathrm{L}_{4}(74.00), \mathrm{L}_{11}(35), \mathrm{L}_{3}(80), \mathrm{L}_{7}(9)$ and $\mathrm{L}_{1}(46) \mathrm{cm}$ respectively. Treatments showed different results according to regarding parameters while tendrils were present and coiled.
\end{abstract}

KEYWORDS: Praecitrullus fistulosus analysis germination, flowering, male and female flower ratio, length of vine and tendrils

\section{INTRODUCTION}

Tindagourd (Praecitrullus fistulosus) is the member of cucurbitaceae family and it is one of the unique and important summer annual vegetable grown almost wide range of IndoPakistan. It is palatable and good in taste recommended by chefs and medical doctors so it is considered as Dilpasand. Plants of cucurbitaceae family are herbaceous and climbing annuals which include seven hundred species and about ninety genera that have additional characters which are having tendrils typically in coiled shape and five angled semi hard stems [1].

Tinda gourd mainly cultivated and grown in the plain areas where sea level approximately altitude of one thousand meter, where they required sunny warm conditions of in between 25 to $30^{\circ} \mathrm{C}$ at day light. In night it requires $18^{\circ} \mathrm{C}$ but gains less in cooler climate and humidified areas of coast level. In east India the growing season of Tinda is either in dry season from February to April and also in rainy season on monsoon mid of June to end of July. The roots of Tinda required light sandy soils where it penetrates easily in depth. More fertile to less fertile is suitable for early open end of the vegetative cover [2].
Unisexual flowers are somewhat action morphic always. Prolonged and short epigenous zone perianth that carries 3 to 6 calyx lobes and 3 to 6 petals in amount and 3 to 6 lobed corollas are present. Androecium which are highly variable if consisted of five basically connate stamens which are distinct and frequently twisted, less in amount and folded. Compound and pistil carpels are carrying gynoecium at style branches with one lobed style attached to stigma with some carpels in it, and ovary with having one locule which carries 2 to 5 placental ovules with many ovules or may be three locules in placental axil point [3].

It sounds good when we achieved level of significant of gene diversity is remain preserved and easily available to growers. It helps in achieving high yield of crops and neglected Tinda and other vegetable food crops which are not used either on country and in worldwide research programs which are known as minor and neglected vegetable crops [4].

The real achievements are considered in this research are on the base of this field experiment, the morphological and taxonomic characters were to determine the amount of diversion within

Copyright: (-) The authors. This article is open access and licensed under the terms of the Creative Commons Attribution License (http://creativecommons.org/licenses/by/4.0/) which permits unrestricted, use, distribution and reproduction in any medium, or format for any purpose, even commercially provided the work is properly cited. Attribution - You must give appropriate credit, provide a link to the license, and indicate if changes were made. 
Tinda (Praecitrullus fistulosus) specie cultivars and to observe the degree of diversion which are related to potential of cultivars are to observe the current status of its morphology by using statistical techniques.

\section{MATERIAL AND METHODS}

The field research was conducted in the Olericulture field of Institute of Horticultural Sciences, University of Agriculture, Faisalabad during 2017 session. The site situated in Faislabad Pakistan was elevated at $186 \mathrm{~m}$ above the sea level. The lines were planted on beds and starts at early April month in 2017. Ten seeds were sown on each single bed. No chemical treatment was used before seed sowing. The layout of crop was done by ploughing and planking before sowing and FYM recommended dose were mixed in it. Sixteen varieties with one check included were used as material by using randomized block design RCBD and three replications. The seed material was obtained from NARC, Islamabad. Each bed contains 10 plants and bed size was $15 \times 5 \mathrm{ft}$ where Plant to Plant distances were maintained at $1.5 \mathrm{ft}$ and Bed to Bed were maintained at $2 \mathrm{ft}$ respectively. First irrigation was done immediately after sowing of seeds. Hoeing and weeding were done at 14 to 15 days of interval when the soil in moist slightly. Recommended NPK fertilizer was mixed in soil before sowing. Canal water is used to irrigate the Tinda beds two times in a week due to raise in temperature. Intercultural practice is done to avoid competition between weeds and vines. Three plants per lines were marked for data recording and recorded data were observed and compiled after taking their mean averages. Data on Germination percentage, days to flowering, male flower ratio, female flower ratio, length of vine in $\mathrm{cm}$ and tendrils were subjected to statistical analysis using the STATISTIX statistical software (Version 8.1) and the mean values were compared using least significant difference (LSD) multiple range test P:0.5\% [5].

\section{RESULTS AND DISCUSSIONS}

All influencing factors are directly involved on lines of tinda gourd germplasm which include sowing date of Tinda seeds, cultural practices during research period, environmental factors that are faced, genetic diversity of a Tinda lines when compared and their modification, available nutrients in soil and nature and habitat of plants [6-7]. 75 percent of NPK which is recommended dose and FYM in included in soil to enhance growth parameters. A similar major improvement in growth parameters due to addition of fertilizers and recommended dose has been reported by [8] in cucurbits, [9] and in tinda gourds and $[10]$ in cucurbits vines.

The presenting data in Table 1 indicate that maximum germination percentage for Tinda lines was observed in local check variety $\mathrm{L}_{0}$ which is (94.00) percent when compared to other genotypes lines. There was a clear significant difference in lines or germination percentage. Between them, the variety $\mathrm{L}_{4}$ showed $74 \%$ germination percentage which is closely followed by line $\mathrm{L}_{6}$ (76.66) and line $\mathrm{L}_{11}$ (77.66) percent. Similar results were concluded by [11] in muskmelon, in which he stated that late
Table 1: Growth assessment of tinda gourd (Praecitrullus fistulosus) germplasms

\begin{tabular}{lccccc}
\hline Lines & G\% & DTF & MF & FM & LV $(\mathrm{cm})$ \\
\hline $\mathrm{L}_{0}$ & $94.00 \mathrm{a}$ & $54.33 \mathrm{a}$ & $99.00 \mathrm{bc}$ & $11.33 \mathrm{ab}$ & $55.33 \mathrm{a}$ \\
$\mathrm{L}_{1}$ & $81.33 \mathrm{efg}$ & $38.33 \mathrm{fg}$ & $98.67 \mathrm{bc}$ & $11.33 \mathrm{ab}$ & $46.33 \mathrm{f}$ \\
$\mathrm{L}_{2}$ & $86.33 \mathrm{bcd}$ & $42.66 \mathrm{de}$ & $88.00 \mathrm{defg}$ & $10.00 \mathrm{~b}$ & $50.33 \mathrm{~cd}$ \\
$\mathrm{~L}_{3}$ & $77.33 \mathrm{ghi}$ & $45.00 \mathrm{~cd}$ & $80.67 \mathrm{~g}$ & $12.66 \mathrm{ab}$ & $47.66 \mathrm{ef}$ \\
$\mathrm{L}_{4}$ & $74.00 \mathrm{i}$ & $39.66 \mathrm{ef}$ & $82.33 \mathrm{~g}$ & $12.33 \mathrm{ab}$ & $51.33 \mathrm{bc}$ \\
$\mathrm{L}_{5}$ & $80.66 \mathrm{efgh}$ & $47.33 \mathrm{bc}$ & $90.33 \mathrm{cdefg}$ & $10.00 \mathrm{~b}$ & $48.33 \mathrm{def}$ \\
$\mathrm{L}_{6}$ & $76.66 \mathrm{hi}$ & $42.66 \mathrm{de}$ & $84.33 \mathrm{fg}$ & $10.00 \mathrm{~b}$ & $54.00 \mathrm{a}$ \\
$\mathrm{L}_{7}$ & $87.00 \mathrm{bc}$ & $49.33 \mathrm{~b}$ & $94.00 \mathrm{bcdef}$ & $9.00 \mathrm{~b}$ & $51.33 \mathrm{bc}$ \\
$\mathrm{L}_{8}$ & $81.00 \mathrm{efg}$ & $38.00 \mathrm{fg}$ & $101.33 \mathrm{ab}$ & $12.66 \mathrm{ab}$ & $53.33 \mathrm{ab}$ \\
$\mathrm{L}_{9}$ & $82.33 \mathrm{def}$ & $50.00 \mathrm{~b}$ & $96.00 \mathrm{bcde}$ & $11.66 \mathrm{ab}$ & $50.00 \mathrm{cde}$ \\
$\mathrm{L}_{10}$ & $79.33 \mathrm{fgh}$ & $39.66 \mathrm{ef}$ & $90.00 \mathrm{cdefg}$ & $11.66 \mathrm{ab}$ & $48.33 \mathrm{def}$ \\
$\mathrm{L}_{11}$ & $77.66 \mathrm{ghi}$ & $35.33 \mathrm{~g}$ & $110.33 \mathrm{a}$ & $14.33 \mathrm{a}$ & $51.33 \mathrm{bc}$ \\
$\mathrm{L}_{12}$ & $89.33 \mathrm{~b}$ & $47.66 \mathrm{bc}$ & $97.67 \mathrm{bcd}$ & $12.66 \mathrm{ab}$ & $47.66 \mathrm{ef}$ \\
$\mathrm{L}_{13}$ & $90.00 \mathrm{ab}$ & $44.33 \mathrm{~cd}$ & $94.33 \mathrm{bcdef}$ & $9.33 \mathrm{~b}$ & $48.66 \mathrm{def}$ \\
$\mathrm{L}_{14}$ & $79.66 \mathrm{fgh}$ & $43.00 \mathrm{de}$ & $96.33 \mathrm{bcde}$ & $10.33 \mathrm{~b}$ & $49.66 \mathrm{cde}$ \\
$\mathrm{L}_{15}$ & $84.00 \mathrm{cde}$ & $46.66 \mathrm{bc}$ & $87.00 \mathrm{efg}$ & $9.33 \mathrm{~b}$ & $50.00 \mathrm{cde}$ \\
$\mathrm{LSD}^{\mathrm{N} D}$ & 4.06 & 3.64 & 10.51 & 3.88 & 2.38 \\
\hline
\end{tabular}

$\mathrm{G} \%=$ Germination percentage, DTF $=$ Days to flowering, $\mathrm{MF}=$ Male

flower, $F M=$ Female flower, $L V=$ Length of vine

sowing will require minimum number of days for germination in muskmelon due to raise in temperature.

The maximum days required by line to flowering were noted down in local check variety which is $\mathrm{L}_{0}(54.33)$ days when compared to other genotype lines. There was a significant difference in lines for days to flowering. All them, the variety $\mathrm{L}_{11}$ showed up 35 days to flower which is closely followed by line $\mathrm{L}_{1}(38.33)$ and line $\mathrm{L}_{8}$ (38.00). Similar findings were also observed by [11] in muskmelon.

The maximum male flower amount during whole time were observed in $\mathrm{L}_{11}(110.33)$ when compared to other genotype lines and the local variety $\mathrm{L}_{0}(99.00)$ which is used as check. There was a noticeable difference in male flowering lines. Among them, the line $\mathrm{L}_{3}$ showed 80 total male flower ratios closely followed by $\mathrm{L}_{4}(82.33)$ in whole period. The appearance of first male flowers had occurred in the main stem or primary branch itself, even before pinching and shedding itself, hence this practice had not had any much effect of first male flowers quantity and appearance. This result is in conformity with the results reported by [12] in bitter gourd.

The maximum female flowers of lines were recorded in line $\mathrm{L}_{11}$ (14.33) when compared to other genotype lines and local variety used as check $\mathrm{L}_{0}(11.33)$. There were a much significant differences in female flowering lines. Among them, the line $\mathrm{L}_{7}$ showed total 9 female flower ratios closely followed by line $\mathrm{L}_{13}(9.33)$ and line $\mathrm{L}_{15}(9.33)$. By higher rate of photosynthesis and accumulation of photosynthates due to it fact of a greater number of leaves, leaf area and efficiencies might had made this higher numbers of female flowers production. This is in conformity with the results reported by [13].

The maximum length of vine of Tinda gourd was observed in local check variety $\mathrm{L}_{0}(55.33)$ and in $\mathrm{L}_{6}(54.00)$ when compared to other genotypes. There was a significant difference in vine 
length for lines. Among them, the line $\mathrm{L}_{1}$ showed $46 \mathrm{cmin}$ length closely followed by line $\mathrm{L}_{3}$ (47.66) and line $\mathrm{L}_{12}$ (47.66). The decrease in vine length could probably be due to decrease in microbial population and activity and not easy availability of macro and micronutrients by application of NPK [14-15]. Earlier report [16] in bottle gourd and in pumpkins are in support with this findings.

Tendrils are lateral and extra axillary leaves which are thread like in nature and spirally coiled a constant organ present on vines of cucubrbitaceae. The only genus where tendrils are absent is known as Ecballium. Tendrils are not available in earlier and in young seedlings of cucurbits because it arises after $4^{\text {th }}$ to $7^{\text {th }}$ nodal stage after seedling grows [17]. In recorded lines of tinda gourd germplasms, the tendrils are mainly present and coiled shaped in all of its genotypes.

\section{CONCLUSION}

Through these growth parameters, the amount of diversity within Tinda (Praecitrullus fistulosus) cultivars were observed clearly and the degree of accessions differentiation were detected.

\section{REFERENCES}

1. Kader AA. Pre- and postharvest factors affecting fresh produce quality, nutritional value, and implications for human health. Proceedings of the international congress food production and the quality of life, sassari, Italy, September, 2002;1:109-119.

2. Sultana S. Indigenous knowledge of folk herbal medicines by the women of district Chakwal, Pakistan. Ethnobotanical Leaflets. 2006;1:26.

3. Akwaowo EU, Ndon BA, Etuk EU. Minerals and anti nutrients in fluted pumpkin (Telfairia occidentalis Hook f.), Food Chem. 2000;70:235-240.

4. Rasul MG, Hiramatsu M, Okubo H. 2007. Genetic relatedness (diversity) and cultivar identification by randomly amplified polymorphic DNA (RAPD) markers in teasle gourd (Momordica dioica Roxb.). Sci. Hortic. 111:271-279.

5. Steel RGD, Torrie JH. Principles and Procedure of Statistics. McGraw Hill Book Co., Inc. Singapore, 1997;173-177.

6. Bhunia SR, Chauhan BS, Yadav BS, Bhati AS. Effect of phosphorus, irrigation and rhizobium on productivity, water use and nutrient uptake in fenugreek (Trigonellafoenum-graecum). Indian J. Agron. 2006; 51:239-241.

7. Kumar S, Singh D, Nepalia V. Performance of fenugreek (Trigonellafoenum-graecum) verities at various fertilizer levels and biofertilizer inoculations. Indian J. Agric. Res. 2002;79:80-83.

8. Chattoo A, Singh KDN, Prasad M. Effect of organic manures and biofertilizers on growth and yield of garlic. Indian J. Agric. Sci. 2007;82(1):31-34

9. Chettri M, Thapa U. Effect of biofertilizers and plant growth promoting bacteria on growth attributes and tuber yield of potato (Solanum tuberosum L.) Haryana J. Hort. Sci. 2006;35(122):143-145.

10. Zayed MS. Improvement of growth and nutritional quality of Moringa oleifera using different biofertilizers. Annu. Agric. Sci. 2012;57(1):53-62.

11. Farooq MM. Effect of different time of sowing on the yield and quality of muskmelon under agro-climatic conditions of Dera Ismail Khan. M.Sc. Thesis, Department of Horticulture, Faculty of Agriculture, Gomal University, DI Khan, Pakistan. 1992.

12. Rasco OA, Castillo SP. Flowering patterns and vine pruning effects in bitter gourd. Philippine Agriculturist. 1990;73(4):311-322.

13. Singh BM. Effect of pruning, spacing and fertilizer levels on flowering, fruiting, yield and quality of muskmelon. Haryana J. Hort. Sci. 1982;12(1):64-68.

14. Azarmi R, Fiveh PS, Satari MR. Effect of vermicompost on growth, yield and nutritional status of tomato (Lycopersiconesculentum). Pak. J. Biol. Sci. 2008;11(140):1797-1802.

15. Ekinci M, Dursun A. Effects of different mulch materials on plant growth, some quality parameters and yield in melon (Cucumis melo L.) cultivars in high altitude environmental condition. Pak. J. Bot. 2009;41(4):1891-1901

16. Hamid RB, Maral M, Nesa H. Effects of vermicompost application and nitrogen fertilizer rates on fruit yield and several attributes of eggplant (Solanum melongena L.) in Iran. World Appl. Sci. J., 2011;15(2):175178.

17. Singh S.P. Biodiversity in shape, size and colour of flowers and fruits of cucurbits. Biodiversity, Breeding, and Production in Uttar Pradesh. 2013;pp. 1-108. 